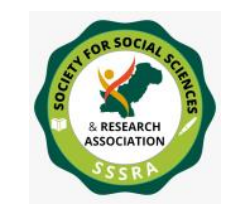

\title{
CHINA- PAKISTAN ECONOMIC RELATIONS: A REVIEW OF FIRST TWO DECADES OF 21ST CENTURY
}

\author{
Syed Muhammad \\ Research Scholar \\ Faculty of Humanities \& Social Sciences, \\ Hamdard University \\ Karachi-Pakistan \\ smsaeed67@gmail.com \\ Prof. Dr. Sayeda Daud \\ Faculty of Humanities \& Social Sciences, \\ Hamdard University \\ Karachi-Pakistan \\ sayedadaud@gmail.com \\ Prof. Dr. Farooq Aziz \\ Faculty of Humanities \& Social Sciences, \\ Hamdard University \\ Karachi, Pakistan
}

\begin{abstract}
China - Pakistan have celebrated more than 6 decades of true friendship. Both countries have cooperated in various fields i.e. economic, political, defence and cultural etc. This research focused on the economic relationship between both states during the first two decades of the $21^{\text {st }}$ century. In this research, it is tried to find out and present the positive and negative points of these relations. Research briefly described the gradual improvement in bilateral relations. The depth of friendship can be determined by the Chinese statement when they declared Pakistan as dear as Israel for the United States. Recently, the most important project CPEC has diverted all the attention of global politics and geopolitics and it is being called the game-changer in the region. This research is qualitative and would base upon interviews, books and articles to reach on a conclusion and bring out a clear picture of the advantages and even disadvantages of various projects advanced by China in Pakistan. The way of bilateral trade has been discussed and suggestions are prepared to make this trade more
\end{abstract}


beneficial in favour of Pakistan. China has proved himself in the list of super-economical powers and now it's up to Pakistan how to use this bilateral relation in the benefit of both states.

KEYWORDS: Economic relationship, Pakistan, China, 21 ${ }^{\text {st }}$ Century, Chinese interest, CPEC

\section{INTRODUCTION}

Pakistan recognized China soon after its inception on 1st of October,1951. Amid the countries belonging to the non-communist bloc, Pakistan was the third country who recognized China. Pakistan supported China during their Korean War and opposed the UNO resolution in which China was declared as an aggressor. And thus the diplomatic relations between both countries started and gradually became stronger. In UNO Pakistan supported the resolution to restore the legitimate rights of China, which resulted in better relations..(Kiyani, 2013). Pak-China relations have been nourishing for the last 60 years in various departments even both countries also have disputes during this period, but they sat together to resolve the issues. Both countries respect their internal integrity. They never had such an issue which seriously affect their relationship. (Rakists,2012)

Some important events from 2015 are as follows.

TIMELINE OF CHINA PAKISTAN BILATERALTRADE from 2005 TILL 2020

- 2005 - An MOU on the most important field of current century IT (Information Technology) was signed by both countries. (The Daily Dawn, 2005)

- 2005 - Chinese Premier Wen Jiabao visits Pakistan. (People's Daily online,2005)

- 2005 - "Treaty of Friendship, Cooperation and Good Neighborly Relations" is signed between the two countries. (People's Daily online, 2005) 
- 2006 - Honorable President of China Mr Hu Jintao paid an official visit to Islamabad. (Daily Dawn, 2006)

- 2006 - FTA (Free Trade Agreement) was signed by both states. (Daily Dawn, 2006)

- 2008 - Pakistan welcomes the Chinese Olympic Torch in Islamabad. (Daily, The Nation, 2008)

- 2010 - Chinese Premier Wen Jiabao visits Pakistan. (Defense.pk.2010)

- 2013 - During the midsummer in May, Chinese Premier Mr Li Keqiang visited Islamabad to negotiate to different issues. (Daily Dawn, 2013)

- 2013 - The largest agreement between both states CPEC (China Pakistan Economic Corridor) was signed in July 2013 linking Xinjiang province with Gwadar sea-port. (Daily dawn, 2013)

- 2014 - To beautify the city of Lahore, Pakistan and China both singed a project to construct Orange Line Metro which would have a length of $27 \mathrm{~km}$. (Daily Dawn, 2014)

- 2015 - During the official visit of honourable President Mr Xi Jinping to Pakistan in 2015 more than fifty agreements were signed about infrastructure, energy and industrial development. (Daily Dawn, 2015)

- 2015 - By the passage of time the trade between both countries increased and in the year 2015, Year of Friendly Exchanges was celebrated. During this year trade between both states crossed the limit of US $\$ 16$ billion. (Daily Dawn, 2015)

- 2016 China-Pakistan unveils the Long-term Plan of China-Pakistan Economic Corridor (CPEC), paving the ways for further cooperation and collaboration. (Global Times, 2020)

- $2018 \quad$ CPEC enters in its Second Phase (MOFA Pakistan) 


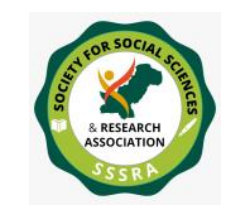

China- Pakistan Economic Relations...

- 2018 Phase-II of China-Pakistan Free Trade Agreement was signed (MOFA Pakistan)

- 2019 CPEC Authority has been set-up to coordinate and monitor progress on CPEC Projects (MOFA Pakistan)

- 2020 Extensive bilateral coordination in the wake of the Coronavirus pandemic; China is the major contributor who extended the largest amount of assistance to Pakistan in fighting the outbreak. (Global Times, 2020)

All events can be described as a brief description of the relations of both countries.

\section{LITERATURE REVIEW}

The roots of the friendship of both states are very deep and clear. Friendship is founded on the pillars of bilateral respect and benevolence for each other. It is proved by the phenomena that highest officials i.e. Prime Ministers, Presidents etc paid visits regularly to strengthen the relations and to sort out the problems of each other. Thus bypassing time the mutual understanding, respect and co-operation between both states grownup and both countries set the examples of friendship and co-operation. Being the most developed country in the region and a large economic and industrial power, China played his role effectively in this friendship. China helped Pakistan to overcome the energy issues and also helped to build infrastructure not only in developed cities but in remote areas too. Being the largest trading partner China's exports to Pakistan also have a great number in percentage. It has a great impact and influence on mutual trade \& economic relationship. It was the first time in 2014 when the trade between both states crossed the target of 16 billion US \$. In 2012 the trade was at the mark of 12 billion US \$ between both countries. During the year from 1995 to 2007, the trade volume between both countries was almost 20 billion US \$. China invested just 0.4 million US \$ in 2004 and it increased by the time and during the year 2013, they invested 5 to 7 billion US\$ in Pakistan. (Small 2015, p 93-115). CPEC has proven as a real game-changer not only for the region but for the trade relationship between both states. After launching this project Chinese investment boost up and both states are quite positive and serious enough about completing this project within the time limit. 


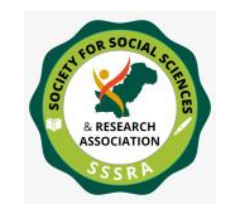

CPEC is a part of a huge Chinese initiative OBOR (One Belt One Road). The main purpose of OBOR is to connect China with the rest of the world to improve their trade and economic activities. CPEC also has the same object to connect China with the Middle East, Gulf states and Central Asia on the shortest route. For this China offered Pakistan to help in improving communication system of Pakistan and also to make infrastructure situation better in remote areas. CPEC is a combination of small projects including roads and power sector. The relation between Pak-China is not only on the state level but it is on people level too. People of both states have mutual respect. 2015 was the year when Pak-China friendship was celebrated by both countries on every level. Various cultural events, seminars and exchange of officials were made on that occasion and it was repeated that both states will continue their journey to prosperity and co-operation with each other. .(Daily Dawn, 2014)

\section{CHINESE INTEREST IN PAKISTAN}

China became independent in 1949 but very soon it started to progress and development and soon became an important power of the region and today it is one of the most influential states of the world. Pakistan and China both have common interests associated with each other. No doubt China has become a great economic power and it is working throughout the world to increase its markets and trade. The first interest of China is to gain power in the region and the only opponent for them is India. India is a great opponent for China and China supports Pakistan against India to boost up Pakistani zeal against India.

Secondly even not like India but yet Pakistan is a big market and China does not want to lose the market. Chinese products have easy access in Pakistan and Pakistan is a great importer of Chinese products. Pakistan has a frail economical structure and China needs a stable Pakistan to produce difficulties for India.

Kashmir is the most important issue for Pakistan and in the same way Tibet is very important for China. India highlights Tibet issue on international forums and Pakistan always supports the Chinese point of view whereas China supports Pakistani point of view on Kashmir dispute and rejects Indian claim on Kashmir. 


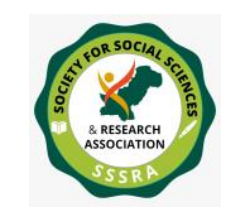

Pakistan and China had conflicts over border issues but they settled mutually, on the other hand, India did not get away to resolve problems with China, this is a reason both countries had a war in 1962 which caused to increase antagonism between both states. A proverb is there that enemy of an enemy is a friend and this can apply to Pakistan and China in the context of India.

The most important thing for any country in the current scenario is trade. China seeks access to the gulf and Central Asia and Pakistan would help China in this. Gawadar Port is a key point for this trade and China does not want to lose this opportunity. Xinjiang is connected with Gawadar through roads, pipelines and have a plan to connect both cities through railway track in future. Gawadar would help China to connect with the rest of the world easily. CPEC is mainly designed to connect China with this part of the world and to make trade more than easy for China. Gawadar has its importance because of its geographical location. The importance of this port can be understood by the figures of $2 / 3^{\text {rd }}$ oil reserves of the world located here. Gawadar Port is at a junction of three regions; Central Asian states, Oil-rich Middle East countries and countries of South Asia regions can be the benefits of this port. As Chinese western ports are far away from these regions so China is taking a keen interest in this port as it is the shortest route for them. This road and port will reduce the Indian influence and significance in the region and this is the reasons that Indians are opposing CPEC badly. India is supporting Chabahar (Iran) to access Afghanistan and Central Asian markets. To get importance in the region India wants to eliminate both CPEC and Gawadar port plans but still, they are not successful. (Sabeen, 2016, the nation) 
Net FDI Country Wise (FY 2001 - 10)

Figures in: US Million Dollars

Source: State Bank of Pakistan

\begin{tabular}{|l|r|r|r|r|r|r|r|r|r|r|r|r|}
\hline Country & $2000-01$ & $2001-02$ & $2002-03$ & $2003-04$ & $2004-05$ & $2001-05$ & $2005-06$ & $2006-07$ & $2007-08$ & $2008-09$ & $2009-10$ & $2006-10$ \\
\hline China & 0.1 & 0.3 & 3.0 & 14.3 & 0.4 & 18.1 & 1.7 & 712.0 & 13.7 & -101.4 & 8.0 & 634.0 \\
\hline
\end{tabular}

Source: SBP

\section{Net FDI Country Wise (FY 2011 - 20)}

Figures in: US Million Dollars

Source: State Bank of Pakistan

\begin{tabular}{|l|r|r|r|r|r|r|r|r|r|r|r|r|}
\hline Country & $2010-11$ & $2011-12$ & $2012-13$ & $2013-14$ & $2014-15$ & $2011-15$ & $2015-16$ & $2016-17$ & $2017-18$ & $2018-19$ & $2019-20$ & $2016-20$ \\
\hline China & 47.4 & 126.1 & 90.6 & 695.8 & 340.8 & $1,300.7$ & $1,048.3$ & 763.2 & $1,311.9$ & 130.8 & 844.1 & $4,098.3$ \\
\hline
\end{tabular}

Souce: SBP

Million US\$

Country China

2000-01 0.1

2001-02 0.3

2002-03 $\quad 3.0$

2003-04 $\quad 14.3$

2004-05 $\quad 0.4$

2001-05 $\quad 18.1$

2005-06 $\quad 1.7$

2006-07 $\quad 712.0$

2007-08 $\quad 13.7$

2008-09 -101.4

2009-10 $\quad 8.0$

2010-11 $\quad 47.4$

2011-12 $\quad 126.1$

2012-13 $\quad 90.6$

2013-14 $\quad 695.8$

2014-15 $\quad 340.8$

2015-16 $\quad 1048.3$

2016-17 $\quad 763.2$

2017-18 $\quad 1311.9$

2018-19 $\quad 130.8$

2019-20 $\quad 844.1$

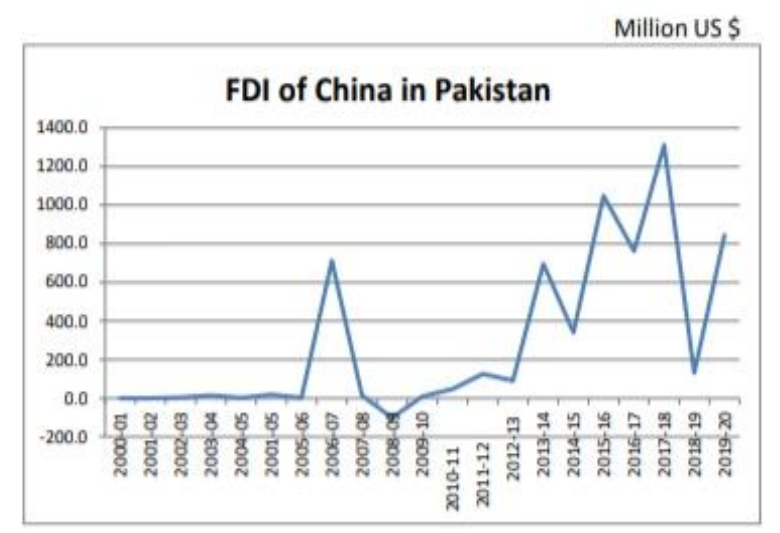




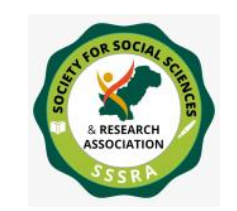

Pak. Journal of Int'L Affairs, Vol 3, Issue 2 (2020)

China- Pakistan Economic Relations...

\section{CHINA PAKISTAN ECONOMIC CORRIDOR (CPEC)}

This mega project which has been famously termed as a 'Game Changer' is a collection of various projects of improvement and building of infrastructure in less privileged areas of Pakistan, especially in KPK and Baluchistan. Estimated expenditure of this project is almost 46 billion US \$ when started and is increasing day by day. The main purpose is to connect China with Gwadar port and besides that a rapid change in Pakistan transportation system and to modernize the economy and providing modern facilities to the dwellers of these areas.

More than $1000 \mathrm{~km}$ motorway will be built between Karachi and Lahore under CPEC project and Karakoram highway which connects Rawalpindi with China will be reconstructed in a modern way. Main Railway line of Pakistan from Karachi to Peshawar will be upgraded to allow the trains to move with the speed of $160 \mathrm{~km} / \mathrm{h}$ and this project will be supposed to be completed till December 2019. Then gradually Pakistan railway will be connected with Xinjiang railway station in Kashghar. This overhauling would need approximately 11 billion US \$.

The main need for Pakistan is energy. Pakistan is badly trapped in an energy crisis and more than 33 billion US \$ will be spent on energy infrastructure that would be helpful to overcome Pakistan energy crisis. It is estimated that by the end of 2018 almost $10,500 \mathrm{MW}$ energy would be generated and added to the national grid of Pakistan. Besides that projects of pipelines for transporting natural liquid gas and oil will also be spread throughout the country to reduce the transportation amount. Approximately 2.5 billion US $\$$ will be spent on gas pipeline from Gwadar to Nawabshah for transporting gas imported from Iran.

It has been said that CPEC is as much important for Pakistan as Marshall Plan was important for Europe after World War. It has been estimated by Pakistan that because of CPEC approximately 2.3 million jobs will be generated between the years 2015 to 2030 and the national economy will boost up about 2 to $2.5 \%$.

Increasing the volume of the project China announced in November 2016 that addition $\$ 8.5$ billion will be invested in Pakistan. Almost $\$ 4.5$ billion are reserved for upgrading Railway line from Karachi to Peshawar and $\$ 4$ billion are allocated for LNG (Liquid Natural Gas) terminals and its transmission lines. These projects 


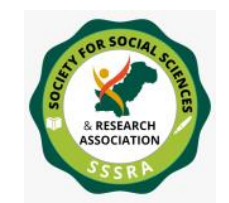

will help reduce energy shortfalls in Pakistan. In February 2017 the project came more worthy when Egypt showed interest in CPEC. In March 2017 more projects were signed including an oil refinery, irrigation projects and motorway between Chitral and D. I. Khan along with Hydro-Electric projects. (Mehmood Safdar, p 383 -385 )

On the current situation on the ground, both countries have continued to increase their participation in CPEC, with contracts worth $\$ 11$ billion approved since 25 June and 6 July 2020. The new contracts include two hydropower projects worth $\$ 3.9$ billion. They include a $\$ 7.2$ billion contract in the Pakistan-controlled region of Kashmir and a $\$ 7.2$ billion contract for railway reconstruction in the pioneering South Asian country. With the launch of the Exclusive Economic Zone (EEZ) in Faisalabad, Pakistan's Punjab Territory, these achievements have given a boost to CPEC development, which has long been a low priority. This is the right emphasis on the details of reviving CPEC in parts of both Islamabad and Beijing. The progress made has advised both sides to move forward despite reservations expressed by Pakistan and China. That is why, on the Pakistani side, retired Lieutenant General Asim Saleem Bajwa has been appointed head of the ChinaPakistan Economic Corridor Authority (CPECA) office, notwithstanding his opposition analysis. (The Diplomat, CPEC 2.0: Full Speed Ahead)

\section{SUGGESTIONS FOR FURTHER IMPROVEMENTS}

This project needs unity, and objections and reservation of people must be addressed properly and to remove the allegation following steps must be taken.

1) All four provinces and Azad Kashmir should be included in the committee they must have a feeling of ownership for this project and reservation and allegations will be solved within the committee.

2) Project must be transparent. All details of the signed agreement must be provided to the parliamentarian committees.

3) People of Gwadar have serious concerns about this project. They must be taken in confidence at the time of decision making.

4) Gwadar is still lacking basic facilities of life, premium drinking water, quality education and situation of hygiene is worst. These problems must be resolved on a priority basis.

5) In the short term program Nowshehra to Gwadar railway line must be laid to create a sense of equivalence on both sides of River Indus. 


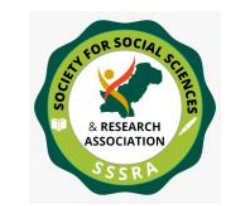

7) Havelian is connected with Khunjrab via railway line but due to natural disasters this line is not safe but a weaker line. As an alternative, a railway line from Gilgit to Shangla and Dargai via Shandor has been proposed which should be considered seriously.

8) CPEC is very important due to its strategic and economical impacts. To make these corridors secure we badly need a reliable infrastructure and communication resources along this corridor.

9) Security is the responsibility of the army so the army should be involved in the planning and execution stages of any sort of projects of CPEC.

10) An authority must be formed for security, implementation and transparency of all projects under CPEC and representatives of all stakeholders of CPEC must be included in that. (Safi Saleem, P 2022)

\section{PAK- CHINA POLITICAL, ECONOMIC AND MILITARY TREATIES}

Economic co-operation between Pakistan and China can be described as following.

1). $\quad$ First trade pact between Pak-China was signed in January 1963.

2) Pak-China joint economical, trade and technological committee was formed in October 1982 and efforts from both sides were to encourage cooperation from both sides.

\section{TRADE AGREEMENTS BETWEEN CHINA AND PAKISTAN}

In 2019 Pakistan exported cotton to China of worth 817.84 million US \$. It was almost $85 \%$ of total trade. Then there comes copper (308.17 million US \$), Cereals (277.99 million US \$), Fish and seafood (135.64 million US \$), Ores, slag and ash ( 86.15 million US \$), Sugar and sugar confectionery (83.61 million US \$), Salt, Sulpher, Earth, Stone, Plaster, Lime \& Cement ( 43.73 million. Articles of apparel, knit etc (34.32 million US \$), Raw hides and skins (27.10 million US \$) (UN COMTRADE 2020)

In 1955 Bandung Conference Prime Minister M. Ali Bogra met with Chinese Prime Minister Zu Nlai. They negotiate in a friendly environment. Both countries were 


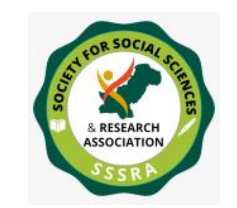

agreed on the point that they need to develop their relations. Those dialogues originally set a trend for both countries to build deep-rooted relations. Bandung Conference led both countries towards the exchange of high official dialogues. (Hasan, 1960)

In March 1963 both countries decided on a disputed area. The area of Zan Chiang and countryside was in Pakistan's control.

In March 1965 Chinese and Pakistani government officials signed on a cultural treaty and the first time both counties agreed to exchange cultural delegations with each other. At that time total, nine agreements were signed.

In March 1966 President Leoshoqi visited Pakistan. Pakistan favoured China on its stance over china status in UNO. 1970 was the decade in which both countries turned new leaves of relationship. (Jakson, 1978)

China helped Pakistan to setup HMC (Heavy Mechanical Complex). HMC is a large factory for engineering instruments construction. It was formed at Taxila, thirty kilometres away from the capital. The administration of this institution is truly professional. This factory is extended up to 231593 sq meter and according to a report, almost eleven hundred workers are working there. It is also ISO 9001 certified. Moreover, the paid capital of HMC was 1077 million rupees. In the end of 1970 in Taxila, a heavy rebuild factory (HRF) was established for rebuilding the tanks and to modernize them. HRF increased its ability in armed vehicles firepower, mobility and protection. Beside that Kamra Avionics and Radar factory was established to prepare ground radar and to rebuild and overhauling of those radars. (Zaheer Shah @ HMC). Pakistani Missile program was started in 1980 with the assistance of China. Pak China missile cooperation was started in 1986 and till then Pakistan has started MKI, MKI-70, and MK2 air defence system assembling. China started helping Pakistan in a large range of missiles. (Daheem, 2012)

\section{CONCLUSION}

In this changing world, China always preferred Pakistan in its policies. China never took any influences from the world on Pak China relations. Pakistan and China have completed harmonization on regional issues and affairs. They have ideal 


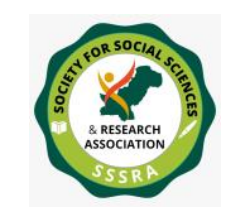

Pak. Journal of Int'L Affairs, Vol 3, Issue 2 (2020)

China- Pakistan Economic Relations...

relations on diplomatic, political, economic ways. On all disputed issues China always supports Pakistan.

China and Pakistan are not only friends but natural allies. The facts are wonderful and delightful for every Pakistani that these relations are going to be stronger to strongest. Pak-China friendship is rightly called deeper than the ocean and mightier than the Himalayas. Both countries work together for peace and integrity in the region. Both countries are ready to gain the utmost benefit from globalization.

Even China is not a member of NAM nor G-7 but yet it always appreciates these two organizations point of view on different issues. China always demanded a new international system. China itself make this rule not to interfere in any one's internal issues. During the past years, China tried his best to increase relations with Muslim countries especially Gulf countries. For Pakistan, China is always a trustful, safety pillar and donor. Being a great power, China is a big hurdle in Indian ways of capturing others. China always supports Pakistan despite the pressure of international rivals. Once, foreign minister of Pakistan said that; "No one except China helped us so generously in the war of 1965." Both countries have the same stance on various issues. In April 1982 on the visit of Pakistani foreign minister $\mathrm{Mr}$ Hawang Hu said; "Both the countries had a deep friendship. This friendship has been absorbed in our blood. History has proven it."

Now America, Russia and India are also trying to create good relations with China. And these efforts have an impact over Pak-China relationship. It seems that Pakistan has no same importance as it had in the '60s, That's why China helped Pakistan in 1965 war but not likewise in 1971. Our graph has been low in term of trade and aid. Through CPEC China is going to capture Pakistan's market, to safe Pakistan's small industries encourage we should make an agreement with China in which Pakistani small industries encourage to work with them toe to toe. Without any doubt, CPEC is a game-changer and Pakistan should change the game wisely in his favour. to make this project successful government officials should add up local officials in this project, it can clear the picture of this project and it will be a clear message for all that CPEC is for the betterment of Pakistan and Pakistanis. CPEC might change the scenario but in short, we should not hope too much from China yet it is still the most favourable country and most trustworthy friend of Pakistan. 


\section{REFERENCES}

Ali, G. (2017). China-Pakistan relations: A historical analysis. Karachi: Oxford University Press. 203-211.

Daheem, Mohammad (2012, October 18). Pakistan's missile capability. Pakistan Observer, http://pakobserver.net/detailnews.asp?id=178539

Embassy of The People's Republic of China in The Republic of Indonesia. (2014, Feburary 25) Xi Jinping Holds Talks with President Mamnoon Hussain of Pakistan, Two Heads of State Agree to Develop Traditional Friendship, Deepen Practical Cooperation, Safeguard Regional Security, and Jointly Forge China- Pakistan Community of Common Destiny id.chineseembassy.org/ eng/gdxw/t1131827.htm

Fingar, C. (2016, March 3) Pakistan FDI Fuelled By China. The New International. https://www.thenews.com.pk/magazine/instep-today/104951-Pakistans-FDIfuelled-by-China

Gates, R. M. (2015). Military and Security Developments Involving the People's Republic of China 2010: Annual Report to Congress. 93-115

Hasan, K. S. (1960). Pakistan and the United Nations. New York: Manhattan Pub. Co.

Iqbal S. (2011). Pakistan-China Strategic Relation: Future Prospects (2009-2011). Lahore: Department of Political Science, University of the Punjab.

Jackson, R. (1978). South Asian Crisis: India. Pakistan, and Bangladesh (London: Chatto and Windus, 1975). 94-95

Kataria, J. R., \& Naveed, A. (2014). Pakistan-China Social and Economic Relations. South Asian Studies (1026-678X), 29(2). 395-410. http://pu.edu.pk/images/journal/csas/PDF/3._Jafar_Riaz_v29_no2_2014.pdf 
Mahmood, S. (2018). International affairs. Lahore: Jahangir Books Publishers. 377-385.

Mahmood, T. (2000). Pakistan's Foreign Policy: Quarterly Survey: January-June 2000. Pakistan Horizon, 53(2/3), 1-13.

Malik, H. Y. (2012). Strategic Importance of Gwadar Port. Journal of Political Studies, 19(2).

(http://pu.edu.pk/images/journal/pols/pdffiles/gwadar\%20article-winter2012.pdf)

Mehmood, K. (2013, July 6). Nawaz's Beijing visit: Trade corridor tops MoU bonanza: Pakistan, China sign eight agreements; fibre optic link will be set up from the Chinese border to Rawalpindi. The Express Tribune http://tribuine.com.pk/story/573220/nawaz-beijing-visit-trade-corridor-topsmou-bonanza/

Pantucci, R. (2014). China in Pakistan: An awkward relationship beneath the surface. RUSI Newsbrief, 15. https://www.rusi.org/publications/newsbrief/ref:A52D6767C1ECA7/\#.U1F FgD2Sxn

Pepe Escobar (2015, April 24). Pakistan enters the new silk route. Asia Times http://atimes.com/2015/04/pakistan-enters-the-new-silk-road/

Rakhmat, M. Z. (2015, June 11). China Goes to Islamabad: The China-Pakistan Economic Corridor. Huffipost http://www.huffingtonpost.co.uk/muhammadzulfikar-rakhmat/china-pakistan_b_7532434.html

Saleem, S. (2019) CPEC: A New Political, Economic \& Strategic Game. Lahore: Sagar Publishers.

Sattar, A. (2010). Pakistan's Foreign Policy: 1947-2009: A Concise History. Karachi: Oxford University Press. 
Shah, Zaheer. (2019) A Symbol of Pak - China Friendship. Heavy Mechanical Complex http://hmc.com.pk/news_events/hmc-a-symbol-of-pak-chinafriendship-article-by-managing-director/

Sinha, P. B. (1982). Gen. Yaqub Ali Khan's Visit to China. Strategic Analysis, 6(3), 169-171.

Small, A. (2015). The China Pakistan axis: Asia's New Geopolitics. London: London C. Hurst \& Co. (Publishers) Ltd. 2-115

Sohail, S. (2016, February 25). China's Interest In Pakistan. The Nation https://nation.com.pk/24-Mar-2016/china-s-interest-in-pakistan

Tao, J. R. (2012). 60. years of Pak-China relations Landmarks. Trends and Approaches, Islamabad: Institute of Policy Studies,.

Trading Economic (n.d.) Paksitan's Exports To China https://tradingeconomics.com/pakistan/exports/china

Umer, M. (2013). Pakistan-China Relations: Problems and Prospects (2001-2011), session 2011-2013, Lahore: Department of Political Science, University of The Punjab. 